\title{
FARMER SATISFACTION ANALYSIS ON RICE FARMING INSURANCE PROGRAM IN TEGAL REGENCY
}

\author{
Mirza Andrian Syah, Mukson, and Wiludjeng Roessali \\ Agribusiness, Faculty of Animal and Agricultural Sciences, Diponegoro University, Indonesia \\ Kampus drh. R. Soejono Koesoemowardojo, Tembalang, Kota Semarang \\ Correspondence Email: mirza.sie9@gmail.com
}

Submitted 11 March 2020; Accepted 2 October 2020

\begin{abstract}
ABSTRAK
Kepuasan petani mengikuti asuransi usaha tani padi (AUTP) menggambarkan performa dari kinerja berjalannya program. Kepuasan program AUTP dapat diukur melalui beberapa atribut kepuasan. Atribut kepuasan yang dinilai tingkatannya mulai dari tidak puas sampai sangat puas. Penelitian dilakukan untuk mengetahui tingkat kepuasan petani terhadap program AUTP. Penelitian dilakukan pada Bulan Januari - Februari 2020. Jumlah sampel yang diambil sebanyak 100 responden menggunakan metode Slovin dan alokasi proporsinal dengan rincian 53 responden diambil di Kecamatan Dukuhwaru dan 47 responden diambil di Kecamatan Warureja yang dipilih secara purposive. Analisis data menggunakan Importance Performance Analysis dan Customer Satisfaction Index. Hasil penelitian menunjukkan bahwa petani merasa puas terhadap berjalannya program AUTP dengan nilai CSI sebesar 79\%. Atribut yang perlu diperbaiki kinerjanya atas hasil analisis IPA adalah syarat ganti rugi, jumlah pertanggungan, prosedur pengajuan, peninjauan, pencairan klaim, dan waktu persetujuan serta pembayaran klaim karena masih belum memenuhi harapan petani.
\end{abstract}

Kata kunci: AUTP, CSI, IPA, kepuasan

\begin{abstract}
Farmers satisfaction in joining Rice Farming Insurance illustrates the program performance. The satisfaction of Rice Farming Insurance program can be measured through some attributes of satisfaction. Satisfaction attributes are assessed ranging from dissatisfied to very satisfied. This research aimed to determine the level of farmer satisfaction on Rice Farming Insurance program. This research was conducted in January - February 2020. Slovin method used for sampling method with total sample of 100 respondent, consist of 53 respondents were taken in Dukuhwaru District and 47 respondents were taken in Warureja District using proportional allocation. Locations in this research was choose with purposive method. Importance Performance Analysis and Customer Satisfaction Index were used to analyze. The result showed that Farmers were satisfied with the implementation of the Rice Farming Insurance program with CSI score of 79\%. The attributes that need to be improved are the compensation requirements, the amount of coverage, the submission procedure, reviewing, and payment procedure of claims, and the time of approval and payment of claims. Those attributes were considered important by farmers yet still have low performance.
\end{abstract}

Keywords: rice farming insurance, CSI, IPA, satisfaction

\section{INTRODUCTION}

Rice Farming Insurance (AUTP) is an attempt performed by the Ministry of Agriculture to address farmers' losses to succeed in achieving the target of food selfsufficiency. It is stated in Law Number 19 of 2013 concerning Protection and Empowerment of Farmers which has been followed up by the issuance of Regulation of 
the Minister of Agriculture No 40 of 2015 concerning Facilitation of Agricultural Insurance. As a result, finally, in 2017, the Ministry of Agriculture has begun to develop the implementation of AUTP.

Rice Farming Insurance is a risk transfer mechanism from the farmers as the insured party to the agricultural insurance as the insurer party in an agreement. The risk transfer mechanism is performed by payment of insurance premiums made by farmers so that the insurer is obliged to pay the losses that occur and this mechanism is guaranteed (Mutaqin et al., 2015). The agreement between the farmers and the insurer is referred to as an insurance policy. The insurance policy is a document of insurance agreement between the farmers and the insurer containing an agreement to binding the insurer to the coverage of rice farming risk.

Farmers who intend to register themselves to participate in the AUTP program are those owning rice fields or sharecroppers who do not own farming land and perform rice cultivation business on an area of at most 2 (two) hectares. The criteria for the location to be registered in the AUTP program are irrigated rice fields and rainfed rice fields which are prioritized in the areas of rice production center with the implementation of Upsus rice (Special efforts for rice).

The affordability of premium payments for agricultural insurance becomes one of the primary factors for farmers to participate in agricultural insurance. The adjustment of premium costs to be paid can improve the demand for agricultural insurance (Liu et al., 2016)., The premium to be paid by farmers in the implemented AUTP program is $20 \%$ of the sum insured, which is IDR $36,000 / \mathrm{ha} / \mathrm{MT}$ of the total premium set at IDR $180,000 /$ ha/MT. The amount of premium (and compensation) that needs to be paid will be counted up proportionally for the insured area of land of less or more than 1 ha.

Based on the AUTP scheme, the costs are borne by the insurance company of PT.
Asuransi Jasa Indonesia is IDR $6,000,000 /$ hectare/MT with a maximum land area for insurance participants of 2 hectares. Compensation provided by the insurance company depends on the level of damage and the planting age of the rice. Full compensation can be provided when the amount of harvest is not more than $25 \%$ of the land area. Submission of claims can be made once the farmers submit or report their losses following the examination results and approval from the insurance company as the insurer (Suarjana et al., 2017). The process of AUTP claim is done using a claim submission mechanism performed by insurance users. After claim submission complete, the insurer will review the losses suffered by the insured party directly. Once the claim is approved, a claim approval letter will be issued and the payment of the claim will be paid within 14 working days starting from the date of claim approval.

Farmers' satisfaction in joining the AUTP program will reveal AUTP's performance as seen from every aspect. Farmers' satisfaction toward the AUTP program needs to be analyzed to find out whether the performance of the program is in line with the farmers' expectations. This study is expected to show the level of satisfaction and attributes in the AUTP program in Tegal Regency.

\section{RESEARCH METHODS}

The study was conducted in JanuaryFebruary 2020 in Dukuhwaru and Warureja Districts, Tegal Regency, Central Java. The method used in determining the location was purposive based on particular consideration, including: 1) Tegal Regency is one of the Regencies in Central Java that has implemented the AUTP program since 2017; 2) In implementing the AUTP program, Tegal Regency is the second-best Regency in Central Java; and 3) Realization of the implementation of the AUTP program in Tegal Regency in 2018 still reached 8,199 hectares from the initial target of 10,000 
hectares (Raswadi, 2018). Dukuhwaru and Warureja Districts were selected as research locations because both districts have the highest number of AUTP participants in Tegal Regency as of October 1, 2019 (Distan \& KP of Tegal Regency, 2019).

The research sampling technique used probability sampling with a purposive sampling approach of sampling with certain criteria. The criteria set include rice farmers who are currently participating in the AUTP program or have participated in the AUTP program before. The number of farmer populations included in this study was 10,437 farmers spread across Dukuhwaru District of 5,549 farmers and Warureja District of 4,888 farmers (Distan \& KP of Tegal Regency, 2019). The method used in determining the sample was the Slovin method by using the following formula:

$$
\begin{aligned}
\mathrm{n} & =\frac{\mathrm{N}}{\mathrm{N}\left(\mathrm{e}^{2}\right)+1} \text { (Sukidin dan Mundir, 2005) } \\
& =\frac{10.437}{10.437\left(0,1^{2}\right)+1} \\
& =99,05100
\end{aligned}
$$

Information:

$\mathrm{n}=$ Sample size

$\mathrm{N}=$ Population size

$\mathrm{e} \quad=$ Accuracy limit (10\%)

According to the above formula, 100 respondents were obtained. This study was conducted by taking random samples scattered in Dukuhwaru and Warureja Districts.
Determination of the number of research sample units that are consisted of two districts used the following method of proportional allocation:

$\mathrm{n}_{\mathrm{i}}=\left[\frac{\mathrm{N}}{\mathrm{Ni}}\right] \mathrm{n}$ (Sugiyono, 2015)

Information:

$\mathrm{n}_{\mathrm{i}} \quad=$ Sample unit / district

$\mathrm{N}=$ Population in each district

$\mathrm{N}_{\mathrm{i}}=$ Total population

$\mathrm{n} \quad=$ Total sample

$$
\begin{aligned}
\text { Dukuhwaru } & =\frac{5.549}{10.437} \times 100 \\
& =53 \\
\text { Warureja } & =\frac{4.888}{10.437} \times 100 \\
& =47
\end{aligned}
$$

Importance Performance Analysis (IPA) was used to identify several attributes attached to services through measuring the level of customer satisfaction (Bitner and Zeithalm, 2003). IPA technique was carried out by assessing the level of importance and performance of an organization. The assessment of the level of importance and performance was performed using a Likert scale with a score interval of $1-5$ by applying the criteria presented in Table 1 .

The attributes observed are the level of importance and performance of the AUTP program measured using the assessment of the AUTP attributes which are based on Premium Assistance Guidelines of the AUTP (Directorate General of Agricultural Infrastructure and Facilities, 2017) involving implementation, registration, claims, and implementer, as can be seen in detail in Table 2.

Table 1. Score of Importance and Performance

\begin{tabular}{ccc}
\hline Likert Scale & Level of Importance & Level of Performance \\
\hline 1 & Very unimportant & Very Unsatisfactory \\
2 & Not important & Not satisfactory \\
3 & Quite important & Good enough \\
4 & Urgent & Satisfactory \\
5 & Very important & Very satisfactory \\
\hline
\end{tabular}

Source: Researcher, 2020 
Table 2. Indicators, Attributes, and Questions of Satisfaction Analysis

\begin{tabular}{|c|c|c|c|}
\hline No. & Indicator & Attribute & Question \\
\hline \multirow[t]{8}{*}{1.} & Implementation & - Guaranteed risk & $\begin{array}{l}\text { 1. AUTP provides a guarantee for damage to the insured } \\
\text { crops caused by some vulnerable risks }\end{array}$ \\
\hline & & $\begin{array}{l}\text { - Terms of } \\
\text { compensation }\end{array}$ & $\begin{array}{l}\text { 2. The specified requirements for compensation due to } \\
\text { damage to the insured crops are not burdensome }\end{array}$ \\
\hline & & - Amount covered & $\begin{array}{l}\text { 3. The amount of compensation provided by AUTP is } \\
\text { highly beneficial for farmers }\end{array}$ \\
\hline & & - Premium fee & 4. The payment of AUTP premium is not burdensome \\
\hline & & - Subsidies & $\begin{array}{l}\text { 5. The amount of premium assistance from the } \\
\text { government highly supports farmers in paying the } \\
\text { AUTP premium }\end{array}$ \\
\hline & & $\begin{array}{l}\text { - The period of } \\
\text { coverage }\end{array}$ & $\begin{array}{l}\text { 6. The agreed period of coverage is in line with the } \\
\text { agreement }\end{array}$ \\
\hline & & - Policy issuance & $\begin{array}{l}\text { 7. Issuance and insurance policies are carried out on time } \\
\text { to farmers }\end{array}$ \\
\hline & & - Outreach & $\begin{array}{l}\text { 8. PPL officers/related offices/Jasindo have a significant } \\
\text { role in AUTP outreach activities }\end{array}$ \\
\hline \multirow[t]{3}{*}{2.} & Registration & $\begin{array}{l}\text { - Registration } \\
\text { process }\end{array}$ & $\begin{array}{l}\text { 9. The process of AUTP registration does not take a long } \\
\text { time }\end{array}$ \\
\hline & & $\begin{array}{l}\text { - Registration } \\
\text { requirements }\end{array}$ & $\begin{array}{l}\text { 10. The requirements set to become an AUTP participant } \\
\text { are not burdensome }\end{array}$ \\
\hline & & - Assistance & $\begin{array}{l}\text { 11. Assistance provided by officers in filling in the AUTP } \\
\text { registration form is really helpful }\end{array}$ \\
\hline \multirow{6}{*}{\multicolumn{2}{|c|}{ 3. Claims }} & $\begin{array}{l}\text { - Procedure for } \\
\text { submitting claims }\end{array}$ & $\begin{array}{l}\text { 12. The procedure for submitting claims is not } \\
\text { burdensome }\end{array}$ \\
\hline & & $\begin{array}{l}\text { - Procedure for } \\
\text { reviewing claims }\end{array}$ & $\begin{array}{l}\text { 13. The procedure for reviewing claims is not } \\
\text { long/complicated }\end{array}$ \\
\hline & & $\begin{array}{l}\text { - Procedure for } \\
\text { assessing claims }\end{array}$ & 14. The procedure for assessing claims is done properly \\
\hline & & $\begin{array}{l}\text { - Time of claim } \\
\text { approval }\end{array}$ & $\begin{array}{l}\text { 15. The time required for notification of claim approval is } \\
\text { not long }\end{array}$ \\
\hline & & $\begin{array}{l}\text { - Procedure for } \\
\text { disbursing claims }\end{array}$ & $\begin{array}{l}\text { 16. The procedure for disbursing claims is timely and not } \\
\text { confusing }\end{array}$ \\
\hline & & $\begin{array}{l}\text { - Time of claim } \\
\text { payment }\end{array}$ & $\begin{array}{l}\text { 17. The period of payment for compensation for claims is } \\
\text { no later than } 14 \text { working days following the official } \\
\text { report on the results of the assessment of the damage }\end{array}$ \\
\hline \multirow{5}{*}{\multicolumn{2}{|c|}{ 4. Implementer }} & $\begin{array}{l}\text { - Department of } \\
\text { Agriculture and } \\
\text { Food Security }\end{array}$ & $\begin{array}{l}\text { 18. Relevant departments are really helpful in terms of } \\
\text { coordination, guidance, outreach, and assistance of the } \\
\text { AUTP program }\end{array}$ \\
\hline & & - PPL & $\begin{array}{l}\text { 19. PPL is really helpful in terms of coordination, } \\
\text { coaching, outreach, and assistance of the AUTP } \\
\text { program }\end{array}$ \\
\hline & & - POPT-PHP & $\begin{array}{l}\text { 20. POPT-PHP is really helpful in terms of coordination, } \\
\text { assessment, and assistance of the AUTP program }\end{array}$ \\
\hline & & - Jasindo & $\begin{array}{l}\text { 21. Jasindo is really helpful in terms of coordination, } \\
\text { coaching, outreach, and assistance of the AUTP } \\
\text { program }\end{array}$ \\
\hline & & $\begin{array}{l}\text { - Chairman of the } \\
\text { farmer group }\end{array}$ & $\begin{array}{l}\text { 22. The chairman of the farmer group is really helpful in } \\
\text { terms of coordination, outreach, and assistance of the } \\
\text { AUTP program }\end{array}$ \\
\hline
\end{tabular}

Source: Modified by Researcher from Various Research, 2020 
The stages of the IPA analysis (Tjiptono, 2011) are as follows:

1. Calculating the average value of the importance and performance levels of each attribute, by using the following formula:

$$
\overline{\mathrm{X}} \quad=\frac{\sum \mathrm{x}_{\mathrm{i}}}{\mathrm{n}} ; \overline{\mathrm{Y}}=\frac{\sum \mathrm{y}_{\mathrm{i}}}{\mathrm{n}}
$$

\section{Information:}

$\overline{\mathrm{X}}=$ The average score of the performance level

$\sum \mathrm{x}_{\mathrm{i}}=$ Total score of performance level

$\bar{Y}=$ The average score of the importance level

$\sum \mathrm{y}_{\mathrm{i}}=$ Total score of importance level

$\mathrm{n} \quad=$ Number of respondents

2. Calculating the average value of the importance and performance levels of each attribute. The average value is then used in determining the boundary for the Cartesian chart, by using the following formula:

$\dot{\mathrm{X}}=\frac{\sum \bar{X}}{\mathrm{k}} ; \dot{\mathrm{Y}}=\frac{\sum \bar{Y}}{\mathrm{k}}$

Information:

$\dot{X}=$ The average score for the performance level of all attributes

$\overline{\mathrm{X}}=$ The average score of the performance level

$\dot{Y}=$ The average score for the importance level of all attributes

$\bar{Y}=$ The average score of the importance level

$\mathrm{k} \quad=$ The number of attributes used
3. Describing the results of each attribute, then develop into the Cartesian diagram as illustrated in Illustration 1.

This Cartesian diagram is divided into four quadrants and each quadrant presents different conditions. Every attribute has a different strategy based on the position of the attribute as follows (Rangkuti, 2006):

1. Quadrant I (Top Priority); This quadrant represents some indicators that are considered to have high importance by farmers, but the performance value is not in accordance with the farmers' expectations.

2. Quadrant II (Maintain Achievement); This quadrant is an area containing some indicators that are considered to have high importance by farmers and have exceeded the farmers' expectations.

3. Quadrant III (Low Priority); This quadrant represents some indicators that are considered to have low importance by farmers and the performance is considered not in line with the farmers' expectations.

4. Quadrant IV (Excessive); This quadrant is an area containing some indicators that are considered to have low importance by farmers but the farmers think that these indicators exceed their expectations.

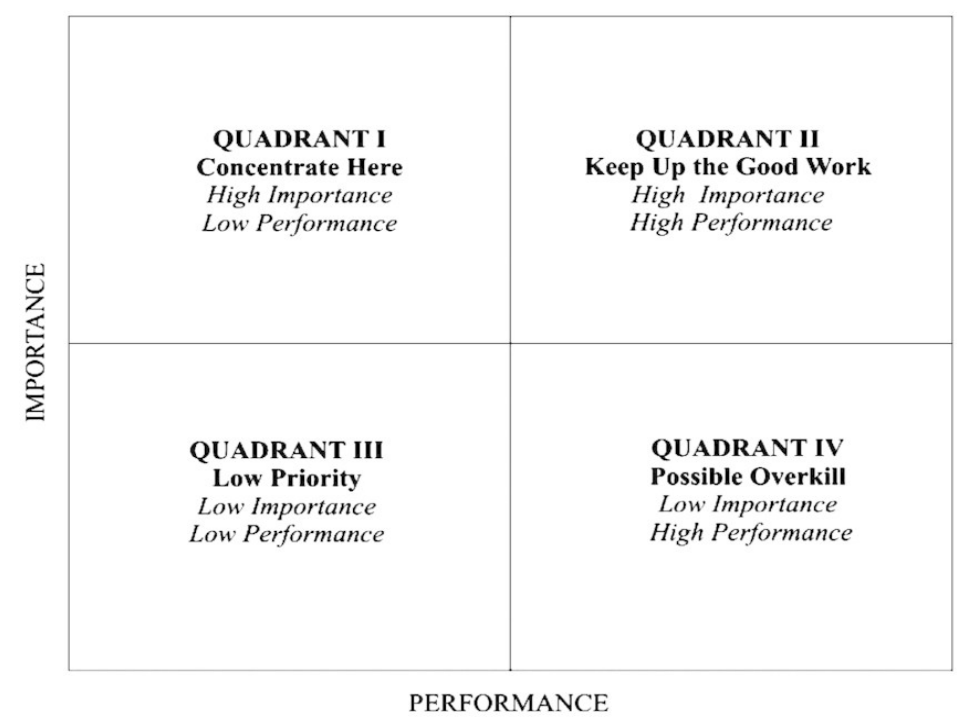

Illustration 1. Cartesian Diagraam for Importace Performance Analysis Source: Modified by Researcher from Various Research, 2020 
The Customer Satisfaction Index (CSI) analysis was carried out to determine how satisfied the farmers with the AUTP program. Satisfaction in the CSI test is observed entirely by considering the importance and performance of the attributes attached to AUTP (Aritonang, 2005). Farmers' satisfaction with the AUTP program is measured by assessing the attributes of AUTP in line with the Premium Assistance Guidelines of the AUTP (2017) including implementation, registration, claims, and implementer. The detailed satisfaction attributes can be seen in Table 2 .

There were 22 questions asked consisting of four indicators, both to assess the importance and performance levels. The stages of the CSI analysis (Aritonang, 2005) are as follows:

1. Determining the Mean Importance Score (MIS) for each attribute. MIS is calculated by using the following formula:

$$
\mathrm{MIS}=\frac{\mathrm{IS}}{\mathrm{n}}
$$

Information:

MIS = Mean Importance Score

IS $=$ Importance Score

$\mathrm{n} \quad=$ Number of respondents

2. Making Weighting Factors (WF) for each attribute. Weighting Factors are a function of the Mean Importance Score (MISi) of each attribute in the form of a percentage (\%) of the total MISi. WF is calculated by using the following formula:

$\mathrm{WF}=\frac{\text { MIS }_{\mathrm{i}}}{\text { Total MIS }_{\mathrm{i}}} \times 100 \%$

Information:

WF = Weighting Factors

MIS = Mean Importance Score

i $=$ Attribute

3. Calculating the Weight Score (WS) of each variable as obtained from:

$\mathrm{WS}=\mathrm{WF} \times \frac{\mathrm{PS}}{\mathrm{n}}$

Information:

WS = Weight Score

WF $=$ Weighting Factors

PS $=$ Performance Score

$\mathrm{n} \quad=$ Number of respondents
4. Calculating the Total Weight Average (WAT) from the Total WS for the first attribute to the $22^{\text {nd }}$ attribute, by using the following formula:

$\mathrm{WAT}=\mathrm{WSa} 1+\mathrm{WSa} 2+\mathrm{WSa} 3+\mathrm{WSa} 4+\cdots+\mathrm{WSa} 22$ Information:

WAT $=$ Weight Avarage Total

WS $=$ Weight Score

a1-22 = Attribute

5. Determining the Customer Satisfaction Index (CSI) by using the following equation:

CSI $=\frac{\text { WAT }}{\text { Highest Scale }} \times 100 \%$

Information:

CSI $=$ Costumer Satisfaction Indeks

WAT $=$ Weight Avarage Total

The minimum satisfaction level is $0 \%$ while the maximum is $100 \%$. A numerical linear scale is determined to find out the scale range (RS) by using this formula.

$\mathrm{RS}=\frac{\mathrm{m}-\mathrm{n}}{\mathrm{b}}$ (Simamora, 2002)

Information:

$\mathrm{RS}=$ Scale range

$\mathrm{m}=$ Maximum score

$\mathrm{n} \quad=$ Minimum score

$\mathrm{b}=$ The number of classes desired

In this study, the scale range is:

$$
\mathrm{RS}=\frac{(100 \%-0 \%)}{5}=20 \%
$$

Interpretation of CSI values is presented in Table 3.

\section{RESULT AND DISCUSSION}

\section{Characteristics of Respondents}

The results of primary data collection using a questionnaire distributed to respondents shows the general description in terms of gender, age, education level, area of land cultivated, land ownership status, and length of working time in farming as presented in Table 4. 
Table 3. Interpretation of CSI values

\begin{tabular}{cc}
\hline CSI Values & Interpretation \\
\hline $0 \%<\mathrm{CSI} \leq 20 \%$ & Very Unsatisfactory \\
$20 \%<\mathrm{CSI} \leq 40 \%$ & Not satisfactory \\
$40 \%<\mathrm{CSI} \leq 60 \%$ & Good enough \\
$60 \%<\mathrm{CSI} \leq 80 \%$ & Satisfactory \\
$80 \%<\mathrm{CSI} \leq 100 \%$ & Very satisfactory \\
\hline
\end{tabular}

Source: Modified by Researcher from Various Research, 2020

Table 4. Characteristics of Respondents

\begin{tabular}{|c|c|c|c|c|c|}
\hline No & Category & $\mathrm{A}$ & $\mathrm{B}$ & Total & Percentage \\
\hline & & & erson & & ---\%"--- \\
\hline \multirow[t]{3}{*}{1} & Sex & & & & \\
\hline & Male & 44 & 46 & 90 & 90,00 \\
\hline & Female & 9 & 1 & 10 & 10,00 \\
\hline \multirow[t]{4}{*}{2} & Age (Years) & & & & \\
\hline & $23-37$ & 4 & 7 & 11 & 11,00 \\
\hline & $38-53$ & 29 & 16 & 45 & 45,00 \\
\hline & $54-69$ & 20 & 24 & 44 & 44,00 \\
\hline \multirow[t]{5}{*}{3} & Education Level & & & & \\
\hline & $\begin{array}{l}\text { Not completed in primary } \\
\text { school }\end{array}$ & 3 & 1 & 4 & 4,00 \\
\hline & $\begin{array}{l}\text { Graduated from elementary } \\
\text { school }\end{array}$ & 12 & 18 & 30 & 30,00 \\
\hline & $\begin{array}{l}\text { Graduated from junior high } \\
\text { school }\end{array}$ & 6 & 7 & 13 & 13,00 \\
\hline & Graduated from high school & 32 & 21 & 53 & 53,00 \\
\hline \multirow[t]{4}{*}{4} & Land Area (ha) & & & & \\
\hline & $\leq 0,5$ & 29 & 15 & 44 & 44,00 \\
\hline & $0,501-2$ & 21 & 31 & 52 & 52,00 \\
\hline & $>2$ & 3 & 1 & 4 & 4,00 \\
\hline \multirow[t]{4}{*}{5} & Land Ownership & & & & \\
\hline & Own & 17 & 25 & 42 & 42,00 \\
\hline & Rent & 22 & 8 & 30 & 30,00 \\
\hline & Sakap & 14 & 14 & 28 & 28,00 \\
\hline \multirow[t]{4}{*}{6} & Farming Experience (Year) & & & & \\
\hline & $<18$ & 17 & 8 & 25 & 25,00 \\
\hline & $18-34$ & 25 & 18 & 43 & 43,00 \\
\hline & $>34$ & 11 & 21 & 32 & 32,00 \\
\hline
\end{tabular}

Information: $\mathrm{A}=$ Dukuhwaru Sub-districts, $\mathrm{B}=$ Warureja Sub-districts

Source: Primary Data, 2020

Table 4 shows that the majority of the farmers are male with a percentage reaching $90 \%$ of the total respondents with the majority of farmers over 37 years old. It shows that the majority of farmers are old and not many young people are involved in the

agricultural sector. It is reinforced by the results of the Agricultural Census in 2013 that $87.13 \%$ of farmers in Indonesia are over 34 years old with the largest age range between 45 - 54 years old of $28.03 \%$ (BPS, 2013). 
The education level of the farmers as presented in Table 4 shows that the majority of the respondents have a good education because $53 \%$ are high school graduates. The cultivated land area of the farmers is fairly narrow. It is shown by $44 \%$ of farmers who have cultivated land area of less than 0.5 ha, while $52 \%$ of them have cultivated land ranging from 0.501 to 2 ha, and only $4 \%$ of them have cultivated land area of more than 2 ha. Based on the ownership, $42 \%$ of respondents own the land by themselves, $30 \%$ of respondents have leased land, and $28 \%$ of respondents have cultivated land with a profit-sharing system between the tenants and the landowners. Based on farming experience, $43 \%$ of respondents have been farming for 18 - 34 years.

As one of the intervention policies implemented by the government, AUTP requires a stage of introduction to its potential targets, which are rice farmers.
The initial stage of introduction is necessary to provide a good impression to farmers and ensure that participating in AUTP will truly protect farmers from the risk of loss. An introduction to the AUTP program for farmers is presented in Table 5.

Table 5 shows that $93 \%$ of the respondents have been offered to participate in AUTP, and $68 \%$ of the respondents have also received previous outreach activities. The outreach activities aim to spread information about the existing insurance program and clarify the AUTP mechanism to farmers. The first source of information for $71 \%$ of the respondents in the introduction of the AUTP program was provided by farmer groups, followed by PPL of $23 \%$. It shows that the chairman of the farmer groups is the party who has the most active role in the introduction of the AUTP program in Tegal Regency.

Table 5. Introduction to the AUTP Program

\begin{tabular}{|c|c|c|c|c|c|}
\hline No & Category & $\mathrm{A}$ & B & Total & Percentage \\
\hline \multirow{4}{*}{1} & & \multicolumn{3}{|c|}{-------person------- } & $---0 \%---$ \\
\hline & Was offered to participate in AUTP & & & & \\
\hline & Yes & 52 & 41 & 93 & 93,00 \\
\hline & No & 1 & 6 & 7 & 7,00 \\
\hline \multirow[t]{3}{*}{2} & Have received socialization & & & & \\
\hline & Yes & 38 & 30 & 68 & 68,00 \\
\hline & No & 15 & 17 & 32 & 32,00 \\
\hline \multirow[t]{5}{*}{3} & First time knowing AUTP & & & & \\
\hline & Farmers Group & 39 & 32 & 71 & 71,00 \\
\hline & Jasindo & 4 & 0 & 4 & 4,00 \\
\hline & Extension Officers & 10 & 13 & 23 & 23,00 \\
\hline & Other Farmers & 0 & 2 & 2 & 2,00 \\
\hline \multirow[t]{3}{*}{4} & Frequency of socialization activities & & & & \\
\hline & $\leq 3 \mathrm{x}$ & 28 & 30 & 58 & 85,29 \\
\hline & $>3 x$ & 10 & 0 & 10 & 14,71 \\
\hline \multirow[t]{6}{*}{5} & Motivation to participate in & & & & \\
\hline & AUTP & & & & \\
\hline & Own initiative & 0 & 0 & 0 & 0,00 \\
\hline & Invited by other farmers & 1 & 6 & 7 & 7,00 \\
\hline & Appeal from farmer groups & 30 & 27 & 57 & 57,00 \\
\hline & There is socialization & 22 & 14 & 36 & 36,00 \\
\hline
\end{tabular}

Information: $\mathrm{A}=$ Dukuhwaru Sub-districts, $\mathrm{B}=$ Warureja Sub-districts

Source: Primary Data, 2020 
$85.29 \%$ of the respondents stated that the outreach activities were done at least three times per year, or at the beginning of each planting season. The outreach activities done at the beginning of the planting season are highly appropriate to do to encourage farmers to participate in the insurance again. Regarding the motivation of the respondents in participating in the AUTP program, $57 \%$ of farmers stated that their decision to join the AUTP was based on the advice provided by the farmer groups. It shows that the farmer groups have a fairly significant role indirectly in terms of assisting the running of the AUTP program along with the functions and tasks of PPL.

\section{The Results of the Importance Performance Analysis}

Farmers' satisfaction towards the AUTP program which is analyzed using importance performance analysis aims to find out the performance of each attribute attached to the AUTP program that is in accordance or not with farmers' expectations. The output of the Cartesian diagram is presented in Illustration 2.

Illustration 2 shows the classification of attributes of satisfaction attached to the
AUTP program. The attributes that are clustered in quadrant I indicate that some AUTP attributes are considered to have high importance by the farmers, but have values of performance that are not in accordance with farmers' expectations. Some attributes in quadrant I are presented in Table 6.

Table 6 shows that the attributes belonging to quadrant I are the majority of claims indicators, where almost all AUTP claims belong to quadrant I. It shows that the claim procedure of AUTP remains far from the farmers' expectations in Tegal Regency. The satisfaction attribute number 2 regarding compensation requirements remains burdensome for the farmers. Land requirements that are allowed to submit AUTP claims according to the AUTP Guidelines of 2017 (Directorate General of Agricultural Infrastructure and Facilities, 2017) are land where the chance of harvesting is less than $25 \%$ of the total land area insured. It is deemed highly burdensome for farmers, particularly for those who have large enough cultivated land. The results of interviews with the respondents show that they expected the requirements regarding the area of damaged land could be reduced by at least $50 \quad-\quad 60 \%$ from $75 \%$.

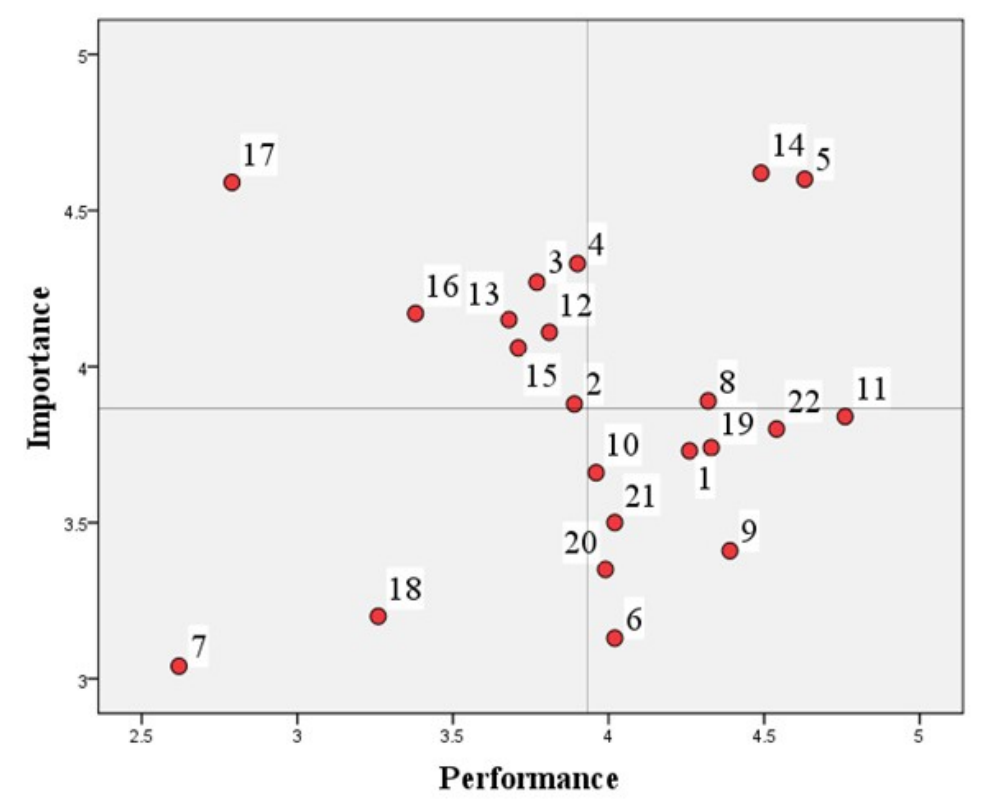

Illustration 2. Cartesian Diagram of Farmer Satisfaction with the AUTP Program Source: Primary Data, 2020 
Table 6. Attributes to the Quadrant I

\begin{tabular}{cll}
\hline No & \multicolumn{1}{c}{ Attribute Statement } & \multicolumn{1}{c}{ Indicator } \\
\hline 2 & $\begin{array}{l}\text { The specified requirements for compensation due to damage to the } \\
\text { insured crops are not burdensome }\end{array}$ & Implementation \\
3 & $\begin{array}{l}\text { The amount of compensation provided by AUTP is highly } \\
\text { beneficial for farmers }\end{array}$ & Implementation \\
4 & The payment of AUTP premium is not burdensome & Implementation \\
12 & The procedure for submitting claims is not burdensome & Claims \\
13 & The procedure for reviewing claims is not long/complicated & Claims \\
15 & The time required for notification of claim approval is not long & Claims \\
16 & $\begin{array}{l}\text { The procedure for disbursing claims is timely and not confusing } \\
17\end{array}$ & $\begin{array}{l}\text { The period of payment for compensation for claims is no later than } \\
\text { 14 working days following the official report on the results of the }\end{array}$ \\
& $\begin{array}{l}\text { Claims } \\
\text { assessment of the damage }\end{array}$ & \\
\hline
\end{tabular}

Source: Primary Data, 2020

These results are in line with a previous study conducted by Geelsya (2020), stating that the attribute of insurance that needs to be improved on the results of the IPA analysis is the requirements for compensation based on the extent of the damage.

Satisfaction attribute number 3 as shown in Table 6 regarding the amount of coverage provided is also deemed insufficient for farmers, particularly for those who have a land area of fewer than 0.5 hectares. The results of interviews with the respondents show that farmers with a land area of fewer than 0.5 hectares are expected to be able to harvest more than the compensation received. The value of the insurance provided is considered insufficient to cover the production costs that have been incurred, particularly for labor and fuel costs for water pumps which swell when the dry season comes. Based on the AUTP Guidelines of 2017 (Directorate General of Agricultural Infrastructure and Facilities, 2017), the insured costs obtained by farmers is IDR $6,000,000 /$ hectare/MT or less than IDR $3,000,000$ for farmers who insure less than 0.5 hectares of their land. The total insured is only about $50 \%$ of the costs incurred in one planting season which can reach IDR $6,000,000$ for a land of 0.5 hectares and does not involve land rental costs. The results of the interview with the respondents show that they expected the amount of coverage provided would increase, at least be able to cover the costs incurred by the farmers. According to Mustika et al. (2019), the amount of claims becomes one of the essential attributes for farmers to participate in the AUTP program. The findings of the research conducted by Geelsya (2020) are in accordance with the results of this study which states that the AUTP attribute that needs to be improved is the number of claims received.

Based on the analysis, it is known that the satisfaction attribute number 4 that the payment of the AUTP premium is not burdensome is classified into quadrant I as shown in Illustration 2. It indicates that farmers have high expectations, wishing that the premiums to be paid are not too expensive. Affordable premiums that need to be paid by farmers to participate in the AUTP program can increase farmers' satisfaction with the running of this program. It is in line with the statements of Siswadi and Syakir (2016) that affordable premiums have a positive effect on the response and willingness of farmers to participate in the AUTP program. Based on an article published by the Provincial Government News Portal of Central Java (2019) the Agriculture and Plantation Agency of Central Java Province, beginning from 2020 , will bear $100 \%$ of the 
premium costs for farmers who are classified as poor. It aims to increase farmers' interest in registering and farmers' satisfaction with the running of the AUTP program.

Table 6 shows that there are five indicators of claims that belong to quadrant I, which are attribute number 12 regarding the procedure for submitting claims that are not burdensome, attribute number 13 regarding the procedure for reviewing claims is not long/complicated, attribute number 15 regarding the time of claim approval, attribute number 16 regarding the procedure for disbursing claims on time and not confusing, and attribute number 17 regarding the period of payment for the claim is no later than 14 working days following the official report on the results of the assessment of the damage. The results of interviews with the respondents indicate that the series of procedures from submitting claims to receiving compensation is considered too long. The limited number of officers from Jasindo caused the AUTP claim process to take a long time. The long process of claims has made some farmers doubt the role of AUTP in assisting farmers. This condition makes some farmers reluctant to participate again in the AUTP program in the next planting season. These results are in accordance with Geelsya (2020) which stated that based on the results of IPA analysis, the AUTP attribute that needs to be improved is the length of disbursement of claims that are considered too long by the farmers.

According to the farmers, the officers in charge of reviewing claims needed a quite long time to visit or about 3-4 days after the claim was submitted by the farmers. Farmers were worried that if the officers did not come immediately, the damaged area would become wider and result in greater losses. Therefore, some farmers decided to harvest the plants that were still safe immediately although the officers had not yet arrived. Likewise, the approval and payment of claims were the same. In reality, the compensation received by farmers was not within 14 working days following the official report on the results of the assessment of the damage, but ranging from two months to one year following the official report on the results of the assessment of the damage. It is in accordance with the research results done by Marphy and Priminingtyas (2019) that the difficulty of the claim process and the time taken for insurance officers to come to survey the land affected by crop failure made farmers distrust the insurance agency and became the reason the farmers difficult to accept the AUTP program and reluctant to pay premiums.

The attributes clustered in quadrant II indicate that some indicators deemed by farmers to have high importance and have exceeded farmers' expectations. Some attributes belonging to quadrant II are presented in Table 7.

Table 7 shows that the attributes belonging to quadrant II consist of satisfaction attribute number 5 regarding premium assistance, attribute number 8 regarding the role of in outreach activities, and attribute number 14 regarding proper claim assessment are done. Attributes belonging to quadrant II are those with high importance and have met the expectations of farmers. The results of the interview show that almost all farmers were willing to participate in the AUTP program because of the premium subsidies.

Table 7. Attributes to the Quadrant II

\begin{tabular}{cll}
\hline No & \multicolumn{1}{c}{ Attribute Statement } & \multicolumn{1}{c}{ Indicator } \\
\hline 5 & $\begin{array}{l}\text { The amount of premium assistance from the government highly } \\
\text { supports farmers in paying the AUTP premium } \\
8\end{array}$ & $\begin{array}{l}\text { PPL officers/related offices/Jasindo have a significant role in AUTP } \\
\text { outreach activities }\end{array}$ \\
14 & Procedures for assessing claims is done properly & Implementation \\
\hline
\end{tabular}

Source: Primary Data, 2020 
The existence of premium subsidies highly supports farmers to pay premiums that are not too expensive. The affordable cost of premiums can increase the chances of farmers with lower incomes to participate in the AUTP program. It is in line with the statement of Safitri et al. (2019) that the premium subsidies give a good assessment of the response of farmers in terms of their perceptions, attitudes, and motives for participating in the AUTP program. The existence of premium subsidies becomes one of the attractions for farmers to be willing to join the AUTP program. Liu et al. (2016) stated that the affordability of premium payments of agricultural insurance becomes one of the primary factors for farmers to participate in agricultural insurance. The adjustment of the premium costs to be paidSource: Modified by Researcher from Various Research, 2020 can improve the demand for agricultural insurance.

Satisfaction attribute number 8 as shown in Table 7 indicates that farmers still need outreach activities to improve their understanding of the AUTP program. The outreach activities performed by PPL officers/related agencies/Jasindo have fulfilled the farmers' expectations. The frequency of outreach activities that are done as often as possible can improve a better understanding for farmers about the running of the AUTP program. Outreach activities that run well can be seen from the high participation of farmers in the AUTP program. It is in line with the statement of Boer (2012) that outreach activities of insurance are needed for farmers to build a better understanding of the insurance program and clarify the work system of the insurance.

Table 7 shows that the satisfaction attribute number 14 regarding the claim assessment has in fact exceeded the farmers' expectations. Even though farmers feel that the claim process is way too long, the actual assessment can improve their confidence in the AUTP program. Based on the results of the interview, the assessment conducted by POPT-PHP and Jasindo was to directly observe the location where the claim was submitted, to take some samples of the crops that died due to pests/plant diseases or drought, document the location, and calculate the area of land where crop failure occurred. The assessments done in fact can build good trust for farmers and increase farmers' satisfaction with the running of the AUTP program.

The attributes clustered in quadrant III indicate that the indicators assessed by farmers have low importance while the performance is deemed not in accordance with farmers' expectations. Some attributes belonging to quadrant III are presented in Table 8.

Table 8 shows that the satisfaction attribute number 7 of the issuance and submission of the insurance policy, still does not meet the farmers' expectations. The results of interviews with the respondents indicate that most farmers did not know about an insurance policy, although the policy was a basic right for every AUTP participant. Moreover, it was found that some farmers who already knew about the policy had never received an AUTP policy since they first participation in the program and did not demand to hold their own policies. It is in accordance with the statement of Azriani et al. (2018) that the issuance of the AUTP policy in Padang City is not immediately given to farmers following registration and the farmers do not demand to hold the AUTP policy.

Table 8. Attributes to the Quadrant III

\begin{tabular}{cll}
\hline No & \multicolumn{1}{c}{ Attribute Statement } & \multicolumn{1}{c}{ Indicator } \\
\hline 7 & Issuance and insurance policies are carried out on time to farmers & Implementation \\
18 & $\begin{array}{l}\text { Relevant departments are really helpful in terms of coordination, } \\
\text { guidance, outreach, and assistance of the AUTP program }\end{array}$ & Implementer \\
\hline
\end{tabular}

Source: Primary Data, 2020 
Table 8 presents the satisfaction attributes number 18 regarding relevant departments that are highly helpful in terms of coordination, coaching, outreach, and assistance of the AUTP program, which belongs to quadrant II. It shows that the involvement of relevant departments in terms of coordination, coaching, outreach, and assistance of the AUTP program is at a low priority. The results of interviews with the respondents indicate that officers from the government's department were rarely seen and involved in implementing the AUTP program. According to Azriani et al. (2018), relevant departments should have a supporting role in AUTP outreach activities without relying solely on extension agents because it is feared that the outreach provided by extension agents without being accompanied by related agencies will not run optimally.

The attributes clustered in quadrant IV indicate that the indicators are considered to have low importance by farmers, but they think these indicators exceed their expectations. Some attributes belonging to quadrant IV are presented in Table 9.
Table 9 shows that the implementation indicators belonging to quadrant IV are satisfaction attribute number 1 that AUTP provides a guarantee for damage to the insured crops caused by some vulnerable risks and number 6 that the agreed period of coverage is in line with the agreement. The implementation of the AUTP program has exceeded the expectations of farmers with the importance that are considered low. Based on the interview results, these attributes have low importance because when the program was introduced, farmers were still in doubt whether the AUTP program would in fact run following the original guidelines and objectives.

Table 9 shows the satisfaction attributes number 9, that process of AUTP registration does not take a long time, number 10 that requirements set to become an AUTP participant are not burdensome, and number 11 that assistance provided by officers in filling in the registration form is really extensive. It is because the average performance of the three attributes exceeds the average farmers' expectations.

Table 9. Attributes to the Quadrant IV

\begin{tabular}{|c|c|c|}
\hline No & Attribute Statement & Indicator \\
\hline 1 & $\begin{array}{l}\text { AUTP provides a guarantee for damage to the insured crops caused } \\
\text { by some vulnerable risks }\end{array}$ & Implementation \\
\hline 6 & The agreed period of coverage is in line with the agreement & Implementation \\
\hline 9 & The process of AUTP registration does not take a long time & Registration \\
\hline 10 & $\begin{array}{l}\text { The requirements set to become an AUTP participant are not } \\
\text { burdensome }\end{array}$ & Registration \\
\hline 11 & $\begin{array}{l}\text { Assistance provided by officers in filling in the AUTP registration } \\
\text { form is really helpful }\end{array}$ & Registration \\
\hline 19 & $\begin{array}{l}\text { PPL is really helpful in terms of coordination, coaching, outreach, } \\
\text { and assistance of the AUTP program }\end{array}$ & Implementer \\
\hline 20 & $\begin{array}{l}\text { POPT-PHP is really helpful in terms of coordination, assessment, } \\
\text { and assistance of the AUTP program }\end{array}$ & Implementer \\
\hline 21 & $\begin{array}{l}\text { Jasindo is really helpful in terms of coordination, coaching, } \\
\text { outreach, and assistance of the AUTP program }\end{array}$ & Implementer \\
\hline 22 & $\begin{array}{l}\text { The chairman of the farmer group is really helpful in terms of } \\
\text { coordination, outreach, and assistance of the AUTP program }\end{array}$ & Implementer \\
\hline
\end{tabular}

Source: Primary Data, 2020 
Farmers feel that the registration procedure which includes the registration process, registration requirements, and assistance in filling out the registration form is not burdensome and as a result, it has high satisfaction to reduced priorities.

Table 9 shows that the satisfaction attribute number 19 of the role of PPL who assist in coordination, coaching, outreach, and assistance, number 20 of the role of POPTPHP who assisst in coordination, assessment, and assistance, number 21 of Jasindo who helps in terms of coordination, coaching, outreach, and assistance, and number 22 of the role of the chairman of the farmer groups who assists in coordination, outreach, and assistance have excessive performance. The farmers feel that the role of assistance during the AUTP program provided by PPL, POPTPHP, Jasindo, and the chairman of farmer groups is really helpful and has exceeded their expectations. It is in line with the statement of Shalihah (2018) that the role of assistance provided by field officers to farmers can provide a good assessment and the possibility of farmers to participate in the AUTP program, considering that field officers are one of the parties who has an important role in disseminating information regarding the program held by the government.

\section{Results of Customer Satisfaction Index}

The results of data analysis show that the value of farmer satisfaction by implementing customer satisfaction index (CSI) analysis is $79 \%$. This value is in the range of more than 60 to 80 percent, indicating that the satisfaction of farmers in Tegal Regency with the AUTP program is categorized as satisfied. It shows that the AUTP program that has been running in Tegal Regency has fulfilled the farmers' expectations. Some improvements and enhancement to the running of the program remain needed to increase farmers' satisfaction and participation in the AUTP program sustainably.

This result is better than the previous study conducted by Mustika et al. (2019) and
Geelsya (2020) where the results of CSI analysis are less than $70 \%$ respectively. It is because the research time was different, allowing some improvements in the implementation of the AUTP program when the researchers conducted this study which led to a higher CSI value. The CSI value obtained was due to the high farmers' expectations for the AUTP program which was accompanied by several benefits received by farmers. Farmers will feel satisfied when their expectations have been fulfilled by the ongoing AUTP program. It is consistent with the statement of Engel et al. (2004) that satisfaction is represented as a postconsumption evaluation of an alternative selected that fulfills or exceeds expectations.

\section{Recommendations for Improvement}

Based on the results of the IPA and CSI analyses, recommendations that can be proposed for the improvement of the AUTP program in the future are as follows:

1. The minimum damaged land area required is better to be reduced from $75 \%$ to 50 $60 \%$. These requirements are deemed too burdensome for farmers as the remaining land is still saved and the amount of compensation that will be received if the claim is approved still does not cover the losses suffered by the farmers.

2. The amount of compensation that will be received by farmers should be given equally to farmers with an insured area of fewer than 0.5 hectares of IDR 3,000,000. It is because the majority of farmers have relatively narrow cultivated land. It is expected that the increase in the amount of compensation for farmers with a narrow area of land can increase their participation in the AUTP program. This recommendation is considered better than providing a $100 \%$ premium subsidy for farmers who are classified as poor because the compensation obtained can be utilized by farmers as capital for the next planting season without having to have debt again.

3. The number of officers from Jasindo should be increased to at least one person 
for one regency/city. It will speed up the assessment process of the claim and will not take a long time. It is different from the current situation in which one officer from Jasindo is in charge of four regencies/cities. The limited number of officers cannot only result in a long time of the assessment process but also drain the energy and time of the officers concerned because they have to go around a very broad location.

\section{CONCLUSION}

Farmers in Tegal Regency were satisfied with the running of the AUTP program with a CSI score of $79 \%$. The attributes whose performance has met the farmers' expectations based on IPA analysis include premium subsidies, outreach, and assessment procedures of the claims. The attributes with excessive performance include the guaranteed risks, the period of coverage, the registration process and requirements, the assistance of PPL, POPT-PHP, Jasindo, and the chairman of farmer groups. The attributes that need to be improved include the requirements of compensation, the amount of coverage, the procedure for submitting, reviewing, disbursing claims, and the time for approval and payment of claims as do not meet the farmers' expectations yet.

\section{REFERENCES}

Aritonang, R. L. 2005. Kepuasan Pelanggan. Jakarta. Gramedia Pustaka Utama.

Azriani, Z., Refdinal, and C. Paloma. 2018. Pelaksanaan asuransi usaha tani padi dalam meningkatkan ketahan pangan di Kota Padang. Prosiding Seminar Nasional dalam Rangka Dies Natalis UNS Ke 42 Tahun 2018: Peran Keanekaragaman Hayati untuk Mendukung Indonesia sebagai Lumbung Pangan Dunia: 36-43.
Bitner, M. J. and V. A. Zeithaml. 2003. Service Marketing, 3rd Ed. New Delhi. Tata McGraw Hill.

Boer, R. 2012. Asuransi iklim sebagai jaminan perlindungan ketahanan petani terhadap perubahan iklim. Prosiding Widyakarya Nasional Pangan dan Gizi X: Pemantapan Ketahanan Pangan dan perbaikan Gizi Berbasis Kemandirian dan Kearifan Lokal: 685-700.

BPS. 2013. Laporan hasil sensus pertanian 2013.

https://st2013.bps.go.id/st2013esya/bo oklet /at0000.pdf. Accessed on 23 February 2020.

Dinas Pertanian dan Ketahanan Pangan Kabupaten Tegal. 2019. Data peserta AUTP Kab. Tegal sampai Bulan Oktober 2019. Unpublished.

Direktorat Jendral Prasarana dan Sarana Pertanian. 2017. Pedoman bantuan premi asuransi usaha tani padi tahun anggaran 2017. http://psp.pertanian.go.id/assets/file/20 19/Pedoman $\% 20$ Bantuan $\% 20$ Premi $\%$ 20Asuransi $\% 20$ Usahatani\%20Padi \%20Tahun\%202019.pdf Accessed on 26 June 2019.

Engel, J. F., R. D. Blackwell, and P. W. Miniard. 2004. Consumer Behavior, 8th Ed. Orlando. The Dryden Press.

Geelsya, Y. 2020. Analisis tingkat kepuasan petani terhadap program asuransi usahatani padi (AUTP) di Kecamatan Kuranji Kota Padang. Skripsi. Program Sarjana Universitas Andalas. Padang.

Liu, F., C. P. Corcoran, J. Tao, and J. Cheng. 2016. Risk perception, insurance recognition and agricultural insurance behavior-An empirical based on dynamic panel data in 31 provinces of China. J. Disaster Risk Reduction 20: 19-25. 
Marphy, T. M. and D. N. Priminingtyas. 2019. Analisis faktor-faktor yang mempengaruhi tingkat partisipasi petani dalam program asuransi usahatani padi (AUTP) di Desa Watugede, Kecamatan Singosari, Kabupaten Malang. Jurnal Habitat 30(2): 62-70.

Mustika, M., A. Fariyanti, and N. Tinaprilla. 2019. Analisis sikap dan kepuasan petani terhadap atribut asuransi usahatani padi di Kabupaten Karawang Jawa Barat. Jurnal Forum Agribisnis 9(2): 200-2014.

Mutaqin, A. K., A. Kudus, and Y. Karyana. 2015. Metode parametrik untuk menghitung premi program asuransi usaha tani padi di Indonesia. Jurnal Ethos 5(1): 15-24.

Portal Berita Pemerintah Provinsi Jawa Tengah. 2019. Pemprov Jateng siap biayakan $100 \%$ premi asuransi usaha tani

padi.

https://jatengprov.go.id/publik/pempro v-jateng-siap-bayarkan-100-premiasuransi-usaha-tani-padi/ Accessed on 28 February 2020.

Rangkuti, F. 2006. Measuring Customer Satisfaction. Jakarta. Gramedia Pustaka Utama.

Raswadi, D. 2018. Ratusan petani Tegal terima klaim asuransi. http://www.fokuspantura.com/ swasembada/1670-ratusan-petanitegal-terima-klaim-asuransi. Accessed on 26 June 2019.

Safitri, D., M. Fahmid, and P. Diansari. 2019. Respons petani terhadap program asuransi usaha tani padi (AUTP) di Kecamatan Sajoanging, Kabupaten Wajo, Provinsi Sulawesi Selatan. Hasanuddin Journal of Sustainable Agriculture 1(1): 17-25.

Simamora, B. 2002. Panduan Riset Perilaku Konsumen. Jakarta. Gramedia Pustaka Utama.
Suarjana, I. W., I. W. Widia, and K. Dharmawan. 2017. Penentuan nilai kontrak asuransi usaha tani tanaman kopi arabika berbasis indeks harga internasional. Jurnal Biosistem dan Teknik Pertanian 5(2): 1-7.

Sugiyono. 2015. Metode Penelitian Kuantitatif, Kualitatif, dan R\&D. Bandung. Alfabeta.

Sukidin and Mundir. 2005. Metode Penelitian. Surabaya. Insan Cendekia.

Tjiptono, F. 2011. Service Management Mewujudkan Layanan Prima, 2nd Ed. Yogyakarta. Andi Publisher. 